\title{
Proceeding
}

Supplementary Issue: Winter Conferences of Sports Science. Costa Blanca Sports Science Events, 22-23 March 2021. Alicante, Spain.

\section{Developing of top serve accuracy test on Sepak takraw sport game}

\author{
ROMA IRAWAN ${ }^{1} \triangle$, VIVIEN EDDY PADLI ${ }^{1}$, RULIANDO HASEA PURBA ${ }^{1}$, SELFI AMI SUSANTI ${ }^{2}$ \\ ${ }^{1}$ Faculty of Sport Science, University Negeri Padang, Indonesia \\ ${ }^{2}$ Faculty of Sport Science, Padang State University, Indonesia
}

\begin{abstract}
The serve test in sepak takraw game is a test that aimed to measure the accuracy of serving in sepak takraw game, where the testi stands on the field. This study aimed to develop top serve accuracy test for sepak takraw by adjusting the development of sepak takraw sport in order to find out the server capabilities of sepak takraw athletes. This type of research was a development research. The population of this research was 82 people of sepak takraw soccer athletes aged 15-25 years from west Sumatra. The research sample in the first stage was 20 people and the second stage was 62 people with a purposive sampling technique, because the experienced athletes competed at the regional level to the national level and were male. The results of the study was before the implementation of field trials, an expert validation process was carried out to check the contents of the serve accuracy test for sepak takraw, the percentage of expert evaluations was $91.5 \%$ with very decent category. Furthermore, in the process of analysing the calculation of the validity level in small group trials, the correlation coefficient value of 0.781 was in the very good category and the results of the validity coefficient in the large group trial of 0.812 were also in the very good category. Furthermore, for the level of reliability in small group trials, the correlation coefficient value of 0.896 was in very good category and the results of the reliability coefficient in the large group trial for 0.917 were also in the very good category. The research that would be carried out next was the improvement of sensor-based or digital tools and making assessment norms for groups of women with clear age limits in the coaching of sepak takraw.
\end{abstract}

Keywords: Top serve test; Sepak takraw; Coaching; Sport.

\section{Cite this article as:}

Irawan, R., Padli, V.E., Purba, R.H., \& Susanti, S.A. (2021). Developing of top serve accuracy test on Sepak takraw sport game. Journal of Human Sport and Exercise, 16(3proc), S1330-S1339. https://doi.org/10.14198/ihse.2021.16.Proc3.48

Corresponding author. Faculty of Sport Science, University Negeri Padang, Indonesia.

E-mail: romairawan@fik.unp.ac.id.1

Abstract submitted to: Winter Conferences of Sports Science. Costa Blanca Sports Science Events, 22-23 March 2021. Alicante, Spain.

JOURNAL OF HUMAN SPORT \& EXERCISE ISSN 1988-5202.

(c) Faculty of Education. University of Alicante.

doi:10.14198/jhse.2021.16.Proc3.48 


\section{INTRODUCTION}

Sepak takraw is a sport which originated from the era of the Malay sultanate in 634-713 AD which in Malay language is known as 'sepakraga' (Ahmad Hashim, 2004). Sepak takraw was played for the first time in history in the 15th century. However, at that time, this sport was not called Sepak takraw, but rather 'sepakraga'. The term Sepak takraw comes from the Malay language "Sepak" which means to kick and the word "takraw" which comes from Thai language which means a woven ball (Ambiyar, 2012). The name Sepak takraw was taken from agreement between Malaysia and Thailand, which is the founder of this sport. From the two countries, this sports game has spread to various countries. It even explains that this sport is something amazing, immersive, explosive and is one of the toughest games in the world (Arikunto, 2002).

Sepak takraw began to enter Indonesia in 1970s and in 1971 this sport organization was named Persatuan Sepak takraw Seluruh Indonesia, shortened to PERSERASI (now abbreviated as PSTI / Persatuan Sepak takraw Indonesia). In the early 1980s, the first Sepak takraw National Championship was in Indonesia. As a team sport, Sepak takraw is played on a rectangular, flat surface, both out-doors and in-doors with free PB obstacles $^{3}$. Sepak takraw sport is played by several people. Lots of forms of matches in the sepak takraw sport, and the most popular is team player, where one opposing team consists of 5 players, 3 on the field with 2 substitutes, lined up against each other (Aziz, 2008). Furthermore, the game of sepak takraw was played by two teams, each team consisting of three players, (tekong, left wedge, and right wedge) with two reserve players (Bakar, 2007).

Sepak takraw is a team sport, in achieving a victory, it is determined by many factors, including (1) mastery of the sepak takraw technique individually and (2) good teamwork between players in a team (Baumgartner \& Jackson, 1999). The more perfect the technical mastery of each player and the cooperation of each team, the better quality of the players. To play sepak takraw, a person is required to have abilities or skills in the form of basic abilities which consist of kicking using parts of the legs, playing the ball with the head, chest, thighs, shoulders, and with the soles of the feet. Without mastering the basic skills and basic techniques, Sepak takraw cannot be played properly. Based on the requirements being mastery in basic techniques of the sepak takraw game, the basic techniques of the sepak takraw game can be divided into two, namely basic techniques without the ball and using the ball. In relation to the game of Sepak takraw, basic techniques of playing Sepak takraw include following techniques: (1) serve performed by tekong, (2) petting, (3) smash, (4) heading, and (5) block. In connection with the touch of the ball with limb, certain skills must be mastered by the sepak takraw players which include: (1) kicking; sila kick, horse kick, prying kick, meditating kick with the soles of the feet, and badek or side kick, (2) rocking using the front of the head (forehead), sides and back, (3) using the chest, (4) using thighs, and (5) using shoulders ${ }^{8}$. Serve is a game that starts with bouncing the ball by the left and right flanks which are directed by tekong. Tekong must be ready to serve which is directed to the opponent's area through the top of the net either touching the lip of the net or the net or directly to the opposing court. Its function is to start playing in Sepak takraw. Serve consists of top serve (back of the foot) and buttom serve. Buttom serve is a movement that starts or the main attack is carried out to start the sepak takraw game, because the numbers (points) can only be made by the team serving the serve. Furthermore, another study Serve is a presentation of the first ball in Sepak takraw game. The use of basic serve technique is very important, considering: 1). With serve, a team can produce a point (number), 2). With serve a team can lead the match according to the type of desired, 3) Serve is the first attack on the opposing team.

The importance of serve in Sepak takraw is seen in a game, if a team do failure to serve means that this team's opportunity to get points is lost and it gives the opponent a chance to score ${ }^{9}$. The frequency of serve 
that is not returned from the opponent, is usually the result of the effectiveness and advantage of being able to serve a high ball speed in the right direction of the court. These would be served failures that means the team lost any chance of scoring and giving the opponent a chance to score (Borg \& Gall, 2003; Chen et al., 2018; Denny, 1999). Furthermore, serve also has an important impact on the course of the game, from existing observations that in a match where a team that is able to serve better and successfully will be more dominant in managing the flow of the game and be effective in getting points (Drost, 2011). Many of the players are playing the starting kick (tekong) trying to get score with a hard serve. That's why they serve hard, as a result of which many of them get stuck at the net or off the court, which is very costly. The objective of a serve should be centred on distracting the player, therefore serving should be done in a number of ways in order to confuse the other side of the target and the result of the serve that will be done next. The team serving the serve must be adept at finding the weak spots of the opposing side in order to serve well. Accuracy or punctuality is the ability of a person to direct something carefully to an object, according to their wishes. This requires high concentration of targets.

Based on the researchers' references and views regarding the form of the instrument related to the serve skills of Sepak takraw, it is still limited and has not been developed according to the demands of the Sepak takraw game itself. The serve test in the game Sepak takraw is a test aimed at measuring the accuracy of serving in Sepak takraw game, where the testy stands on the field "in tekong position" and ball is thrown from the right "apit" position, except for left-handed ones that can be done from the left "apit", testi perform serve to the opponent's field and directed at the target plots that have been scored. The score recorded is the score written where the sepak takraw ball falls on the target tile. The ball that falls right on the target grid line, the score is calculated according to the target that has the higher score ${ }^{11}$. For details, look at picture below.

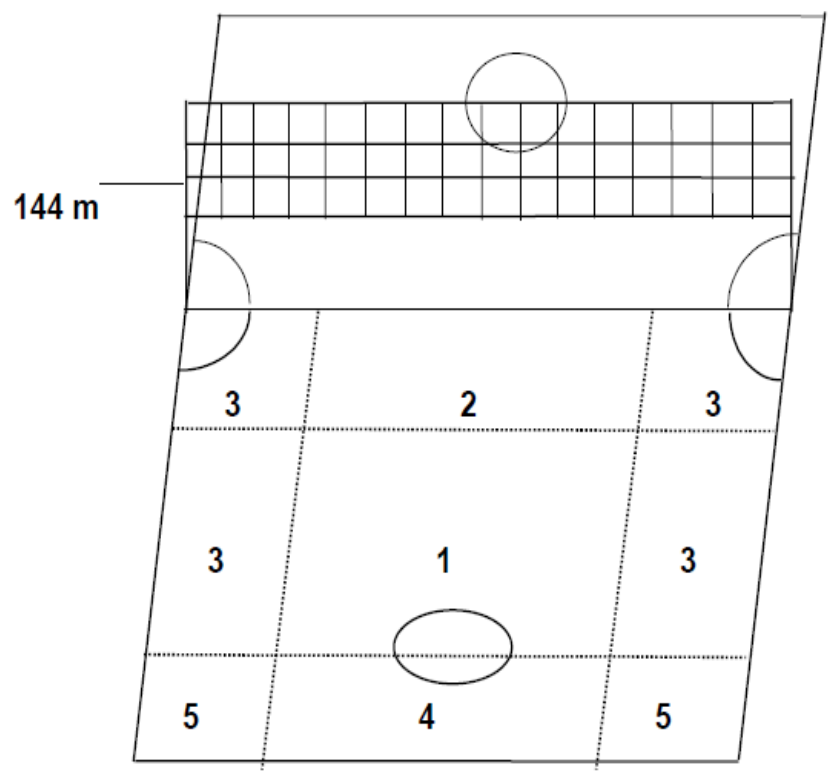

Figure 1. Implementation of serve tests.

Based on the explanation above, there were several illogical target areas in today's modern sepak takraw game. For this reason, there needs to be an innovation or effort to develop an instrument that can measure the accuracy of the top serve in the sepak takraw sport. This study aimed to develop existing instruments, by changing some of the technical implementation. Besides, this study aimed to find the level of validity and reliability of the tests developed in measuring the serve accuracy of sepak takraw sport (Hair et al., 2014). 


\section{METHOD}

The design of this research was in research and development skills test instrument, Borg \& Gall (2003). Where the aimed was to develop a test for the accuracy of the top serve in the Sepak takraw game. The research instrument composed by the researcher consisted of (1) the accuracy of the instrument content, (2) the completeness of the instrument material, (3) the implementation of the instrument. The time needed in research and development with reference to research and development from Borg and Gall takes 4 (four) months with the following details: 1) Needs analysis. 2) Planning model development. 3) Development of training model designs, 4) Expert validation and model revisions, 5) Small group trials and revisions. 6) Field trials and revisions. Development of the top serve tests in Sepak takraw which would be compiled and developed in the form of new and modified instruments.

Table 1. Research design concept.

\begin{tabular}{llcll}
\hline No & Research stage & Number of subjects & Criteria & Instrument \\
\hline 1 & Preliminary research & 3 & Sepak takraw lecturer & Observation and interview \\
\hline 2 & Expert evaluation & 3 & $\begin{array}{l}\text { 2 Coaches } \\
\text { Lecturer }\end{array}$ & Questionnaire sheet \\
\hline 3 & Small group Trials & 20 & Sepak takraw players & $\begin{array}{l}\text { Draft serve test for } \\
\text { Sepak takraw }\end{array}$ \\
\hline 4 & Large group Trials & 62 & 62 players & $\begin{array}{l}\text { Finalization of Sepak } \\
\text { takraw serve test }\end{array}$ \\
\hline
\end{tabular}

The subject-taking technique applied in this study was saturated sampling / census, which was also known as all members of the population used as research subjects. The research was conducted at several places based on the conditions where the athlete was training. The research subjects were athletes from several districts and cities who strengthened their regions for regional and national championships, as shown in the table below:

Table 2. Research population.

\begin{tabular}{lll}
\hline No & Name of club & Amount \\
\hline & PPLP West Sumatera Province & 17 People \\
& Club of SMP 18 & 15 People \\
& Klub Universitas Negeri Padang & 29 People \\
& Pengkot PSTI Kota Padang & 21 People \\
\hline Total & & $\mathbf{8 2 ~ P e o p l e ~}$ \\
\hline
\end{tabular}

The instrument for data collection was used observation guidelines in compiling a test of top serve accuracy in sepak takraw. Observation was used to obtain or capture information from experts as expert judgment provided input and suggestions about the tests to be produced. The number of judges involved was 2 (two) experts in sepak takraw sport and 1 (one) expert in sports tests and measurements. Before being used for data retrieval in the field, the instrument was tested on a small scale and in the final stage to determine the level of validity and reliability. The validity and reliability of the instrument was proven by a simple product moment correlation test.

\section{Top serve test design}

This test aimed to measure the accuracy of the top serve for sepak takraw athletes with the following equipment; Sepak takraw ball, tape measure, chalk, stopwatch, stationery and camera. The field size was as follows: 
a. The field is rectangular with a length of 13.40 meters and a width of 6.10 meters.

b. The distance between line $A$ to line $B$ and line $A$ to line $M$ is the same length, which is 3.05 meters.

c. The distance between line $B$ to line $C$ and line $M$ to line $L$ is the same length, which is 1 meter.

d. The distance between line $C$ to line $D$, line $D$ to line $E$ and line $L$ to line $K$ and line $K$ to line $J$ is the same, which is 2.35 meters.

e. The distance between line $F$ to line $G$, line $G$ to line $H$ and line $H$ to line $I$ is the same length of 2.03 meters.

Furthermore, the implementation of the test was:

1. Testes stand in Tekong circle and prepare to perform serves and researchers and research assistants were on the edge of the field to monitor and observed errors in implementation.

2. The ball was floated by (the researcher) and the teste served the serve towards the specified destination.

3. The position of the helper observed the score and recorded the predetermined serve score.

Meanwhile, to get a score in the implementation of the serve test for Sepak takraw can be seen in these guidelines:

1. If the ball falls on the box with number 1 then the value is 1 .

2. If the ball falls on the box with the number 2 then the value is 2 .

3. If the ball falls on the box with the number 3 then the value is 3 .

4. If the ball does not cross the net or leave the field then the score is 0 .

5. The teste is given the opportunity for 10 repetitions of the serve with one execution.

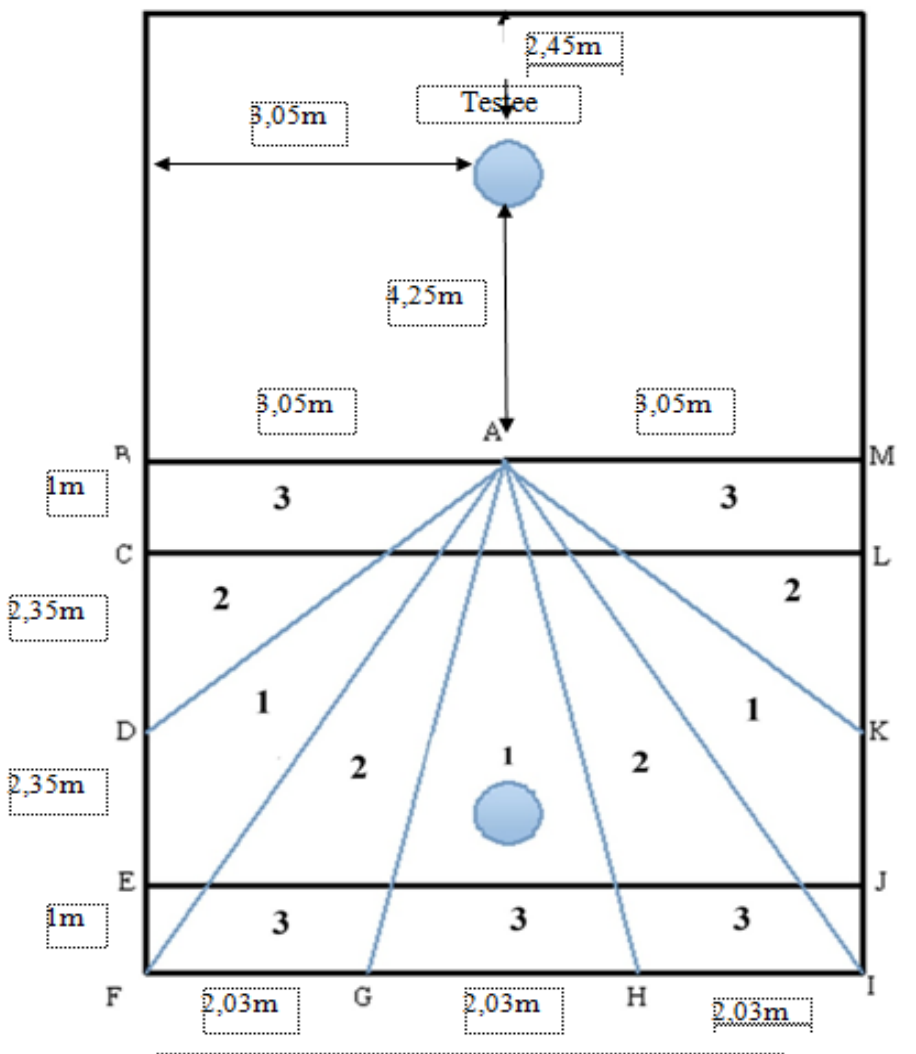

Figure 2. The concept of developing a serve test for Sepak takraw. 


\section{RESULTS AND DISCUSSION}

From the results of this study, it was obtained a measuring instrument for top serve accuracy in sepak takraw sport which has a level of validity and reliability in accordance with the criteria in a measuring instrument. From the results of expert validation, the percentage of the assessment was $91.5 \%$. This can be interpreted that the measuring instrument for top serve accuracy in the sport of Sepak takraw was in a good or proper category. Development of a test for top serve accuracy in the sport of Sepak takraw was in the form of an instrument which was in accordance with the development of the game of Sepak takraw itself. The direction of a good top serve would determine the success in achieving a victory in a match. It was hoped that the development of top serve accuracy test in Sepak takraw was expected to be used as a reference in improving serve techniques for players in the long-term training process with maximum performance.

\section{Validity and reliability test}

In testing the validity of the test for top serve accuracy in sepak takraw sport, firstly need to establish the criteria as a comparison, namely making the criteria score through a test score that was designed with observation of the top serve technique from the implementation of the top serve test. Meanwhile, to find the reliability of the top serve accuracy test was to correlate the first day implementation test data with the second day implementation test data. The results of the calculations were summarized in the table below:

Table 3. Summary of validity and reliability test results.

\begin{tabular}{llcc}
\hline No & Description of validity reliability & Validity & Reliability \\
\hline 1 & Small Group Trial & 0.781 & 0.896 \\
2 & Big Group Trial & 0.812 & 0.917 \\
\hline
\end{tabular}

From the table above, it could be seen that the correlation value between the two test implementations of the top serve accuracy test in sepak takraw sport. The results of the small group validity test were 0.781 , and the large group test results were 0.812 . These results indicated that the test was valid and included in the criteria, that the top serve accuracy in sepak takraw sport was included in the criteria of "very good (high)". Furthermore, testing the level of reliability from the small group trial results obtained 0.896 , and the results of the large group trial of 0.917 . These results indicated that the test was reliable and included in the criteria, that the accuracy of the top serve in sepak takraw was "very good". From the explanation above, it was concluded that the test of top serve accuracy in the sport of Sepak takraw can be used or applied to sepak takraw players in West Sumatra Province. This was because on the test results, the validity and reliability of the test showed the results in accordance with the criteria for the level of correlation stated by K. Methew in Ishak (2008).

Table 4. Significance test results of the validity of serve accuracy tests in Sepak takraw sports.

\begin{tabular}{llcccc}
\hline No & Description & $\mathbf{r}$ - validity & $\mathrm{t}$-value & $\mathrm{t}$-table & Conclusion \\
\hline 1 & Small Group Trial & 0.781 & 5.30 & 1.73 & $\mathrm{~N}=20$ / Significant \\
2 & Big Group Trial & 0.812 & 10.77 & 1.67 & $\mathrm{~N}=62 /$ Significant \\
\hline
\end{tabular}

From the table above, it showed that the t-value of the result of Serve Accuracy Test in Sepak takraw was greater than the t-table at a significant level $=0.05$ and $\mathrm{dk}=\mathrm{n}-2$. The conclusion was the degree of validity of Serve Accuracy Test in Sepak takraw was "significant". 
Table 5. Significance test results of the reliability of serve accuracy tests in Sepak takraw sports.

\begin{tabular}{llcccc}
\hline No & Description & $\mathbf{r}$ - validity & $\mathbf{t}$-value & $\mathbf{t}$-table & Conclusion \\
\hline 1 & Small Group Trial & 0.896 & 8.56 & 1.73 & $\mathrm{~N}=20 /$ Significant \\
2 & Big Group Trial & 0.917 & 17.80 & 1.67 & $\mathrm{~N}=62 /$ Significant \\
\hline
\end{tabular}

From the table above, it showed that the t-value of the result of Serve Accuracy Test in Sepak takraw was greater than the t-table at a significant level $=0.05$ and $\mathrm{dk}=\mathrm{n}-2$. The conclusion was the degree of reliability of Serve Accuracy Test in Sepak takraw was "significant".

\section{Serve accuracy norms in Sepak takraw sport}

After the analysis of validity and reliability test was carried out, the next step was to determine the assessment norm. In accordance with the purpose of this research being carried out was the Serve Accuracy Test in Sepak takraw, then the final stage of the process of finalizing the tool was determining the norm of assessment. In determining the assessment norms, according to the criteria of the tool, namely the sickle kick speed instrument for adult athletes ( 15 to 25 years). The population and sample consisted of 82 males of sepak takraw athletes in West Sumatra Province. The following were the assessment norms:

Table 6. Evaluation norms of serve accuracy test in Sepak takraw.

\begin{tabular}{lc}
\hline Interval & Category \\
\hline$>23$ & Very Good \\
$20-23$ & Good \\
$17-19$ & Enough \\
$15-16$ & Poor \\
$<15$ & Very Poor \\
\hline
\end{tabular}

\section{DISCUSSION}

Based on the data analysis that has been done, it was obtained information about the level of validity of Serve Accuracy Test in Sepak takraw Sport that the researcher designed was in very good category, with the validity coefficient for small-scale trials of 0.781 and large-scale trials of 0.812 . In accordance with the opinion that the number of coefficient values was more than 0.70 is considered to have mastered the highest level in validity level of an instrument (Hamid et al., 2014). So, it could be concluded that the validity level of Serve Accuracy Test in Sepak takraw was at a very good level.

From the description above, it could be understood that the Serve Accuracy Test in Sepak takraw was a test that can be used to measure the ability of Sepak takraw athletes to perform serve techniques for Sepak takraw. Sepak takraw coaches could use the test to measure the serve ability of athletes and sepak takraw players in West Sumatra province. The trainer must be able to carry out the test under strict control (quality control). This strict control can be carried out in several ways, for example: choosing a tester (test taker) who really understands and is able to carry out the Serve Accuracy Test in Sepak takraw, adjusting the age level and age of the teste with test objectives and completing the test facilities (equipment) used, test execution time, and so on. The reason for the low degree of validity of a test was thought to be caused by these things. Because of the weak control over these things, the degree of validity of a test was low.

The efforts to select or determine the test that will be used with the aim of measuring the extent of sepak takraw athletes ability on a skill (technique) so the trainer must have knowledge in terms of choosing a good and correct test. If the test used is correct and good, the information (data) obtained from the measurement 
results is in accordance with what is being measured. Therefore, so that the test used can truly measure what it is trying to measure, the trainer must be able to choose a good and correct test. "The criteria for a good test are valid tests (Hermanto, 2017). A valid test is a test that is able to measure what it wants to measure". If the test used is able to measure what we want to measure, the data obtained from the measurement results will be correct. Then, if the data obtained provides the correct information, the evaluation will be carried out correctly (International Sepak takraw Federation, 2016).

Furthermore, based on the data analysis that has been carried out, it was obtained information about the level of reliability of Serve Accuracy Test in Sepak takraw Sports that the researchers designed. From the data analysis obtained based on small group trials that the reliability level of the Serve Accuracy Test in Sepak takraw was in very good category, with a reliability coefficient of 0.896 and a large-scale trial of 0.917 . A reliable test gives consistent results when it was being tested repeatedly. A reliable test would produce stable and accurate data (Jamalong, 2016). Furthermore, Revelle et al. (2009) explained that the Cronbach alpha coefficient value equal to or above 0.90 indicated a perfect score and was very good in terms of consistency across all variables. when Cronbach's alpha coefficient value greater than 0.90 is obtained from an instrument with stable and consistent feedback, it was belonged to be reliable (Marasabessy et al., 2020). By having a very good level or degree of reliability, the serve test for the Sepak takraw test can be used to measure serve skills for sepak takraw (Miller, 2013). This can increase the player's confidence and can be conveyed to the coach so that psychological stress when serving on Sepak takraw can be avoided, because stress is a condition of a person's reaction both physically and emotionally (mentally / psychologically) when there is a change in the environment that requires a person adjust (Mohd \& Ahmad, 2005; Persetasi, 1994; Revelle \& Zinbarg, 2009; Ruskin, 2006; Suhron, 2016; Suhron, 2017; Suhron \& Amir, 2018; Suhron \& Zainiyah, 2021). Serving in Sepak takraw can increase the self-esteem of players and coaches when serving on Sepak takraw so that score wins can be obtained, self-esteem is a person's self-assessment in assessing themself, including their abilities (Suhron et al., 2017; Suhron et al., 2019). Coaches and players can maintain the ability to serve on Sepak takraw.

From the description above, it was suggested to trainers or individuals who want to use this test in order to carry it out in accordance with the existing test instructions (Suhron et al., 2020; Sujae \& Koh, 2008). By carrying out the test in accordance with the existing instructions, the tester can perform a rigorous serve test for Sepak takraw. Perform strict control both on the person who will do the test (testor) (Sulaihah et al., 2020; Widiastuti, 2011; Winarno, 2004), the classification or the age level of the athlete who will be tested. Weak control over who carries out the test (testor), determining the age level of the teste, the time of the test, and the means (test equipment) can all be expected to cause a low degree of reliability of a test (Yusuf et al., 2019). One of the causes of low degree of reliability test can be caused by human errors, where the testers do not understand and is not master the implementation techniques of the serve skills test for Sepak takraw. To find the reliability of a test, the tester must carry out the first day of the test and the second day of the test at different times but with the same situation.

Reliability refers to the consistent score achieved by same people when they were retested with the same test on different occasions (Yusuf et al., 2019). Based on this opinion, it can be understood that reliability is the consistency of the tests used to measure a set of skills and knowledge when the same test is carried out at different times. If a test is able to be consistent in measuring what is being measured, then the data from the measurement results are not obtained by chance. So that the data can be analysed and produce correct conclusions. Thus, the conclusion can indeed describe the correct information from what is being measured. 


\section{CONCLUSION}

Based on the results of previous research and discussion, it could be concluded from the results of this study that the creation of a Serve Accuracy Test in Sepak takraw Sport which has a high level of validity and reliability. The results of expert validation obtained an assessment percentage of $91.5 \%$. This means that the Serve Accuracy Test in Sepak takraw was in a good or decent category. The results of calculating the level of validity in the small group trial obtained a correlation coefficient value of 0.781 which was in very good category and the results of the validity coefficient value in large group trials were 0.812 also in very good category. Furthermore, for the level of reliability in the small group trial, the correlation coefficient value was 0.896 which was in very good category and the results of the reliability coefficient value in the large group trial of 0.917 were also in very good category. The next research that would be carried out was to improve sensor-based or digital tools and create assessment norms for groups of women with a clear age limit in coaching sepak takraw sport.

\section{REFERENCES}

Ahmad Hashim, A. (2004). Pengukuran Kecergasan Motor. Tanjong Malim: Quantum Books.

Ambiyar. (2012). Pengukuran dan Tes DalamPendidikan. Padang: UNP Press.

Arikunto. (2002). Prosedur penelitian. Jakarta: Rineka Cipta.

Aziz, I. (2008). Tes Pengukuran dan Evaluasi Pembelajaran Olahraga. Padang: FIK UNP.

Bakar, B.A. (2007). Pengujian, pengukuran dan penilaian pendidikan. Kuala Lumpur: Prospecta Printers Sdn.Bhd.

Baumgartner, T.A., \& Jackson, A.S. (1999). Measurement for evaluation in physical education and exercise sciences (6th ed.). USA: McGraw-Hill, Inc.

Borg \& Gall, (2003). Education Research. New York : Allyn and Bacon.

Chen, S., et al. (2018). Physiological Profile Of Sepak takraw University Players. https://doi.org/10.26480/icecsd.01.2018.63.66

Denny, M. (1999). Bermain Sepak takraw. PB. Persetasi, Jakarta.

Drost, E.A. (2011). Validity and reliability in social science research. Education Research and perspectives, 38(1), 105-123.

Hair, J.F., Black, W.C., Babin, B.J., \& Anderson, RE. (2014). Multivariate Data Analysis (7th ed.). Essex: Prentice-Hall, Inc., Pearson Education Limited.

Hamid, N. A., Abd. Muzaffar Babjan, Abdullah, N. M., \& Ismail, S. (2014). Anthropometric And Physiological Profiles Of Varsity Sepak Takraw Players. International Conference on Innovative Trends in Multidisciplinary Academic Research.

Hermanto, Y. F. (2017). Pengaruh Latihan Bola Gantung Terhadap kemampuan Servis Atas Pada Klub Sepaktakraw Yunior Panggul Kabupaten Trenggalek Tahun 2016. Artikel Jurnal, Program Studi Penjaskesrek, Fakultas Keguruan Dan IImu Pendidikan, Universitas Nusantara PGRI Kediri.

International Sepak takraw Federation. (2016). Sepak takraw Heritage. Retrieved from: https://sepaktakraw.org/index.php/law-of-the-game/

Jamalong, A. (2016). Hubungan Antara Power Otot Tungkai Dan Kelentukan Togok Dengan Kemampuan Servis Bawah Dalam Permainan Sepaktakraw Pada Atlet Sepaktakraw Klub Tunas Muda Kabupaten Mempawah. Jurnal Pendidikan Olah Raga, 4(1), 20-34.

Marasabessy, N. B., Suhron, M., \& No, J. R. M. (2020). Stress Family Experience And Profiles Of Tumor Necrosis Factor Alpha And Interleukin-10 Of Nuaulu Tribe Community With Hunting Activity In Mesoendemic Area Of Malaria. Systematic Reviews in Pharmacy. SRP, 11(11), 1886-1891.

Miller, D. (2013). Measurement by the physical educator why and how. McGraw-Hill Higher Education. 
Mohd, S., \& Ahmad, J. (2005). Pembinaan modul: Bagaimana membina modul latihan dan modul akademik. Penerbit Universiti Putra Malaysia.

Persetasi, P.B. (1994). Majalah Sepak takraw. Edisi 04 Mei 1994. Jakarta: PB. Persatuan Sepak takraw Seluruh Indonesia.

Revelle, W., \& Zinbarg, R. E. (2009). Coefficients alpha, beta, omega, and the glb: Comments on Sijtsma. Psychometrika, 74(1), 145-154. https://doi.org/10.1007/s11336-008-9102-z

Ruskin. (2006). Bahan Ajar Mata Kuliah Sepak takraw. Universitas Negeri Gorontalo.

Suhron, M. (2016). Asuhan keperawatan konsep diri: Self esteem.

Suhron, M. (2017). Asuhan keperawatan jiwa konsep self esteem/Care of Mental Nursing The concept of self-esteem. Jakarta: Mitra Wacana Media.

Suhron, M., \& Amir, F. (2018). Reduce Violent Behavior Schizophrenia: A New Approach Using LT (Laughing Therapy) and DRT (Deep Relaxation Therapy). Indian Journal of Public Health Research \& Development, 9(8), 1518-1523. https://doi.org/10.5958/0976-5506.2018.00948.8

Suhron, M., \& Zainiyah, Z. (2021). How Were Stress Family and INSR (Insulin Receptor) Expression in Polycystic Ovary Syndrome (PCOS) Insulin Resistant in Madurese Tribe?: Indonesia. Systematic Reviews in Pharmacy, 12(1), 170-175.

Suhron, M., Sulaihah, S., \& Yusuf, A. H. (2017). Model of Potential Strengthening and Family Roles in Improving Family Members for ODGJ Adaptability. In Proceeding of The 2nd International Symposium of Public Health (pp. 344-351). Faculty of Public Health Universitas Airlangga. https://doi.org/10.5220/0007514003440351

Suhron, M., Yusuf, A., \& Subarniati, R. (2019). Assessment of Stress Reactions and Identification of Family Experiences in Primary Care Post Restrain Schizophrenia in East Java Indonesia. Mix Method: Sequential Explanatory. Indian Journal of Public Health Research \& Development, 10(12), 1849-1854. https://doi.org/10.37506/v10/i12/2019/ijphrd/192136

Suhron, M., Yusuf, A., Subarniati, R., Amir, F., \& Zainiyah, Z. (2020). How does forgiveness therapy versus emotion-focused therapy reduce violent behavior schizophrenia post restrain at East Java, Indonesia?. International Journal of Public Health, 9(4), 314-319. https://doi.org/10.11591/ijphs.v9i4.20538

Sujae, I.H., \& Koh, M. (2008). Technique analysis of the kuda and sila serves in sepaksepak takraw. Sports Biomech, 7(1). https://doi.org/10.1080/14763140701687552

Sulaihah, S., Hanik, E. N., Suhron, M., Hari, B. N., Mundakir, M., \& Esti, Y. (2020). The Role Of Families Caring For People With Mental Disorders Through Family Resilience At East Java, Indonesia: Structural Equation Modeling Analysis. Systematic Reviews in Pharmacy, 11(9), 52-59.

Widiastuti. (2011). Tes dan Pengukuran Olahraga. Jakarta: PT. Bumi Timur Jaya.

Winarno, M.E. (2004). Pengembangan Permainan Sepaksepak takraw. Jakarta: Center For Human Capacity Development.

Yusuf, A., Suhron, M., \& Subarniati, R. (2019). Assessment of the Kempe Family Stress Inventory in selfcare post-restrain schizophrenia. International Journal of Public Health Science (IJPHS), 8(2), 5559. https://doi.org/10.11591/ijphs.v8i2.18205

Yusup, U., Prawirasaputra, S., \& Usli, L. (2004). Pembelajaran Permainan Sepaktakraw: Pendekatan Keterampilan Taktis di SMU. Jakarta: Departemen Pendidikan Nasional, Dirjen Pendidikan Dasar dan menengah dan Dirjen Olahraga.

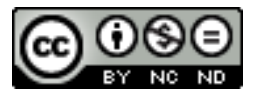

This work is licensed under a Attribution-NonCommercial-NoDerivatives 4.0 International (CC BY-NC-ND 4.0). 